\title{
THE IMPORTANCE OF THE TYPES OF MOTIVATION IN LANGUAGE LEARNING
}

\author{
Mushtariybonu Shoymardon Kizi Yangiboyeva
}

Student Of Denau Institute Of Entrepreneurship And Pedagogy, Uzbekistan

\section{ABSTRACT}

The current case study is divided into two sections. I utilized a questionnaire with twelve questions in the first step. During the second section, I invited participants from Denau Institute of Entrepreneurship and Pedagogy to write an essay or journal entry. I was able to identify their background knowledge and which motivational type is stronger among them by using assignments. Participant A began studying English at a young age and believes that a teacher is essential in motivating her in the learning process. Participant B, on the other hand, does not rely on the teacher and prefers self-study. According to my study, intrinsically driven pupils can achieve better levels of learning.

KEYWORDS:- Motivation, intrinsic, extrinsic, second language acquisition, motivated student, language learning

\section{INTRODUCTION}

Motivation is a frequently used word both in our daily work and study, as it is essential in each sphere of life. Motivation is very vital, and, the same as aptitude, intelligence and attitudes, it is an important factor which can greatly influence the achievement of learners' second language or foreign language acquisition.

The levels and kinds of motivation of any individual are different from others. In other words, not only are the levels and amounts of motivation in individuals different, but their kinds of motivation can also be different. Moreover, there are indeed three main factors which influence second language acquisition; these are age, personality, and motivation. Among the above three issues, motivation is the most significant one in second language acquisition.
Having read many articles on the research topic, I have learned the types of motivation in-depth. Based on my knowledge, I wanted to observe students' language acquisition process and their source of motivation. I tried to research how the kinds of motivation influence language learning. Much research has been conducted on the significance of motivation, but I can add to this that the amount, range, and type of motivation, starting age, learning language, and personality have an important and determining role in the learning process. Moreover, the language teacher has a significant function and role in giving motivation to the learner for learning a language.

\section{Literature Review}

While conducting research, we came to the idea that many researchers frequently define motivation. For instance, Johnstone (1999, p. 146), considers motivation as a stimulant for achieving a specific target. Similarly, according to 
CURRENT RESEARCH JOURNAL OF PEDAGOGICS 2(10): 30-37,

October 2021 DOI: https://doi.org/10.37547/pedagogics-crjp-02-10-07

ISSN 2767-3278

(C)2021 Master Journals

\section{Crossref doi) gr Google}

Accepted 22 ${ }^{\text {th }}$ October, 2021 \& Published $27^{\text {th }}$ October, 2021

Ryan and Deci (2000), "to be motivated" means to progress or to be in motion to do something, while Gardner (1885) believes that with the intention of being motivated, the learner necessitates, requires, and needs to have something to anticipate, foresee, expect, and long for a reason, principle, or rationale having to do with aim or target.

When a learner is highly motivated and determined, they can show progress in the learning process. Learners' personalities and their starting age of learning have an impact on their results.

Two kinds of motivation can be observed among learners; they are high attitude, which has a positive, efficient, and useful effect, and the second one is a low attitude, which makes blocks and causes weakness for learning a language. As it was mentioned before, motivation involves two main classifications, as below:

\section{Intrinsic motivation}

Extrinsic motivation

Obviously, intrinsic motivation is mental satisfaction, which is achieved by others' praise, while extrinsic motivation is an incentive activated by external factors such as good marks and getting a reward.

It is indeed important for the teacher to know that the two types of motivation, intrinsic and extrinsic, relate to each other and are interrelative. In addition, personal, psychological, and social factors affect increasing or decreasing any mentioned type of motivation. The teacher needs to know what the type of motivation is and how it is formed, captured, and, finally, displayed in the learner. Both intrinsic and extrinsic motivations can have two subgroups that can activate the learners. The intrinsic motivation of an extroverted learner is in such a way that the learner takes advantage of and feels satisfied by communicating with others, while in an introverted learner, the learner uses language for meditation and personal thinking in addition to personal activities and affairs. Indeed, relying on intrinsic and extrinsic motivations for either of them, the teacher should make the classroom quiet and without any anxiety. Providing educational and academic advantages, encouraging students, and asking simple and easy questions at the beginning of class (before asking difficult questions) will increase motivation for learning. Besides, the mentioned issues will fulfill the learner's need for progress. Accordingly, the designed encouragement for the classes plays an important role in achieving a good or positive learning outcome. The learner, indeed, should know that his efforts are valued by the teacher. Thus, giving proper and appropriate rewards on account of the language learners' behaviours is the significant and indispensable point. The teacher, furthermore, should consider, pay attention, and, finally, strengthen the language learners' positive behaviors and admirable activities arising from intrinsic, extrinsic, as well as integrated and instrumental motivation (s). In effect, strengthening or reinforcing the expected and desirable behaviours in the language teaching process is accomplished and achieved by encouraging, stimulating the feeling of curiosity and inquisitiveness about the cultures of other nations, presenting and showing a movie, as well as giving chances to the students. Consequently, motivation directly influences and affects the language learner's learning methods, skills, and practices. That is, motivation has a high effect on learners' communication with foreigners, determining learning amount, in addition to developing the desired levels of language teaching such as reading, comprehension, speaking, and writing. Briefly, motivation has a direct effect on both the quality and quantity of language learning.

Hence, I assume that it could be the major 
CURRENT RESEARCH JOURNAL OF PEDAGOGICS 2(10): 30-37,

October 2021 DOI: https://doi.org/10.37547/pedagogics-crjp-02-10-07

ISSN 2767-3278

(C)2021 Master Journals

\section{Crossref doi) google}

Accepted 22 $2^{\text {th }}$ October, 2021 \& Published 27th October, 2021

facilitator of language learning, but there are other factors, too. Edward Deci (1973) claims that intrinsic motivation can also play an integral role in learning a second language. Learners are self-determined to open new horizons in the target language and without external stimuli, they can be successful. It is difficult to portray the fact that one can become intrinsically motivated, some researchers say.

The flow theory is advocated by (Csikszentmihalyi, 1990; Egbert 2004, cited in H. D. Brown, 2014).They believe that external factors inspire people and "burn them inside out". Quite the contrary, extrinsic motivation is a learning process triggered by parents, teachers, and peers (H. D. Brown 2014).

Participant profile

For my case study, I have chosen two students who are learning the English language as a foreign language at Denau institute of entrepreneurship and pedagogy. One of them is Lobar, who is twenty-two years old and came from Bukhara. She started learning English at the age of $16-17$. Her nationality is Uzbek as well as her first language. She is self-motivated and prefers self-study instead of depending on the teacher in the learning process. The second participant is Gulnoza, who is a twenty-threeyear-old girl. She is from Tashkent. She began learning English before puberty. She has been learning this language for more than 11 years. Although Gulnoza's nationality is Uzbek, her family speaks Russian. Gulnoza is also selfmotivated and hard-working, but she believes that the teacher's role is important in the learning process. As for their level, one of them is at an advanced level; the second one of them is intermediate. I have been working with them for 4 weeks and I am surprised by the fact that they have different levels even though they have almost similar cultures, ages, and exposure to English. Therefore, I try to observe their learning background, motivation (both intrinsic and extrinsic), and their strengths and weaknesses.

Research design

\section{The present case study involves two stages:}

Interview questionnaire

Writing assignment on essay

In the first step, I used a questionnaire consisting of twelve questions. The interviews were conducted in English and were recorded in an audio file for about six and five minutes and then transcribed. Most of the questions focused on the types of motivation that influence learners and how they overcame learning difficulties in order to know their motivational strengths. During the interview, I paid attention to the participants' answers and their speech accuracy.

In the second part, I asked them to write an essay or entry. They both wrote good essays on the topic they wanted and 40 minutes were given to write and submit. With the help of assignments, I have a chance to identify their background knowledge and which motivational type is higher for them according to their results.

\section{DATA COLLECTION AND ANALYSIS}

Although the data collection process is likely to be difficult, it is an intriguing part of my research. While working with students, I underwent good linguistic experience for a special purpose. According to their answer, firstly, I categorized them as Participant A (Gulnoza) and Participant B (Lobar) so that I could know what is successful students' source of motivation (whether they are intrinsically motivated or extrinsically motivated). 
CURRENT RESEARCH JOURNAL OF PEDAGOGICS 2(10): 30-37,

October 2021 DOI: https://doi.org/10.37547/pedagogics-crjp-02-10-07

ISSN 2767-3278

(C)2021 Master Journals

Crossref doi 81 Google

Accepted 22th October, 2021 \& Published 27 ${ }^{\text {th }}$ October, 2021

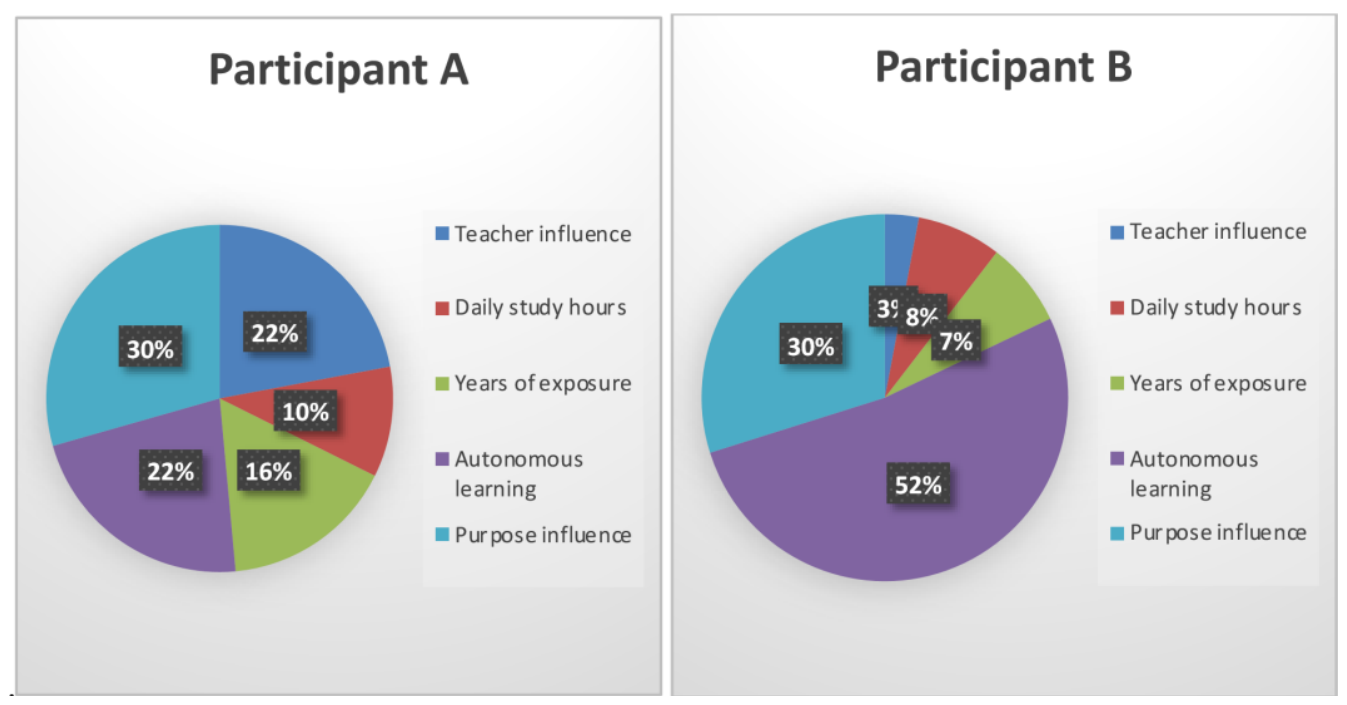

In these pie charts, based on the interview questionnaire answers, I knew that Participant

A started learning English at an early age and spends many hours studying daily. Besides, she considers that teacher is important to motivate her in her learning process. As she is dreamful, she was inspired and determined to achieve her goals. By contrast, Participant B does not depend on the teacher. As a result, she prefers self-study. She started learning the language 5 years ago.
She spends almost 4 or 5 hours studying English. Her purpose also tremendously motivates her to be active.

Having collected sufficient data, I evaluated and analyzed their speaking and writing assignments through the speaking and writing rubric by Brown to check their levels. Speaking rubric 
CURRENT RESEARCH JOURNAL OF PEDAGOGICS 2(10): 30-37,

October 2021 DOI: https://doi.org/10.37547/pedagogics-crjp-02-10-07

ISSN 2767-3278

(C)2021 Master Journals

Crossref doi 81 Google

Accepted 22 $2^{\text {th }}$ October, 2021 \& Published 27th October, 2021

\begin{tabular}{|c|c|c|c|c|}
\hline Fluency & $\begin{array}{c}\text { Pronunciation } \\
\text { and accent }\end{array}$ & Vocabulary & Grammar & Details \\
\hline $\begin{array}{l}\text { Smooth and fluid speech; } \\
\text { few to no hesitations; no } \\
\text { attempts to search for } \\
\text { words; volume is } \\
\text { excellent. }\end{array}$ & $\begin{array}{l}\text { Pronunciation is excellent; } \\
\text { good effort at accent }\end{array}$ & $\begin{array}{l}\text { Excellent control of } \\
\text { language features; a } \\
\text { wide range of well- } \\
\text { chosen vocabulary }\end{array}$ & $\begin{array}{c}\text { Accuracy } \& \text { variety of } \\
\text { grammatical } \\
\text { structures }\end{array}$ & $\begin{array}{l}\text { Excellent level of } \\
\text { description; additional } \\
\text { details beyond the } \\
\text { required }\end{array}$ \\
\hline $\begin{array}{c}\text { Smooth and fluid speech; } \\
\text { few hesitations; a slight } \\
\text { search for words; } \\
\text { inaudible word or two. }\end{array}$ & $\begin{array}{l}\text { Pronunciation is good; } \\
\text { good effort at accent }\end{array}$ & $\begin{array}{l}\text { Good language control; } \\
\text { good range of relatively } \\
\text { well-chosen vocabulary }\end{array}$ & $\begin{array}{c}\text { Some errors in } \\
\text { grammatical } \\
\text { structures possibly } \\
\text { caused by attempt to } \\
\text { include a variety. }\end{array}$ & $\begin{array}{l}\text { Good level of } \\
\text { description; all required } \\
\text { information included }\end{array}$ \\
\hline $\begin{array}{c}\text { Speech is relatively } \\
\text { smooth; some hesitation } \\
\text { and unevenness caused } \\
\text { by rephrasing and } \\
\text { searching for words; } \\
\text { volume wavers. }\end{array}$ & $\begin{array}{l}\text { Pronunciation is good; } \\
\text { Some effort at accent, but } \\
\text { is definitely non-native }\end{array}$ & $\begin{array}{l}\text { Adequate language } \\
\text { control; vocabulary } \\
\text { range is lacking }\end{array}$ & $\begin{array}{c}\text { Frequent grammatical } \\
\text { errors that do not } \\
\text { obscure meaning; } \\
\text { little variety in } \\
\text { structures }\end{array}$ & $\begin{array}{l}\text { Adequate description; } \\
\text { some additional details } \\
\text { should be provided }\end{array}$ \\
\hline $\begin{array}{c}\text { Speech is frequently } \\
\text { hesitant with some } \\
\text { sentences left } \\
\text { uncompleted; volume very } \\
\text { solt. }\end{array}$ & $\begin{array}{c}\text { Pronunciation is okay; No } \\
\text { effort towards a native } \\
\text { accent }\end{array}$ & $\begin{array}{c}\text { Weak language control; } \\
\text { basic vocabulary choice } \\
\text { with some words clearly } \\
\text { lacking }\end{array}$ & $\begin{array}{c}\text { Frequent grammatical } \\
\text { errors even in simple } \\
\text { structures that at } \\
\text { times obscure } \\
\text { meaning. }\end{array}$ & $\begin{array}{l}\text { Description lacks some } \\
\text { critical details that make } \\
\text { it difficult for the listener } \\
\text { to understand }\end{array}$ \\
\hline $\begin{array}{c}\text { Speech is slow, hesitant \& } \\
\text { strained except for short } \\
\text { memorized phrases; } \\
\text { difficult to perceive } \\
\text { continuity in speech; } \\
\text { inaudible. }\end{array}$ & $\begin{array}{l}\text { Pronunciation is lacking } \\
\text { and hard to understand; } \\
\text { No effort towards a native } \\
\text { accent }\end{array}$ & $\begin{array}{l}\text { Weak language control; } \\
\text { vocabulary that is used } \\
\text { does not match the task }\end{array}$ & $\begin{array}{l}\text { Frequent grammatical } \\
\text { errors even in simple } \\
\text { structures; meaning is } \\
\text { obscured. }\end{array}$ & $\begin{array}{c}\text { Description is so lacking } \\
\text { that the listener cannot } \\
\text { understand }\end{array}$ \\
\hline
\end{tabular}

SAR

\begin{tabular}{|c|c|c|c|c|c|c|}
\hline \multirow[t]{2}{*}{ № } & \multirow[t]{2}{*}{ Fluency } & Pronunci & & \multirow[t]{2}{*}{ Vocabul } & Gramm & Deta \\
\hline & & $\begin{array}{l}\text { ation and } \\
\text { accent }\end{array}$ & ary & & ar & ils \\
\hline $\mathbf{P A}$ & 4 & 4 & & 5 & 5 & 4 \\
\hline PB & 3 & 2 & & 3 & 4 & 2 \\
\hline
\end{tabular}

Writing rubric 
CURRENT RESEARCH JOURNAL OF PEDAGOGICS 2(10): 30-37,

October 2021 DOI: https://doi.org/10.37547/pedagogics-crjp-02-10-07

ISSN 2767-3278

(C)2021 Master Journals

Crossref do: II Google

Accepted 22th October, 2021 \& Published 27 ${ }^{\text {th }}$ October, 2021

\begin{tabular}{|c|c|c|c|c|}
\hline Category & 4 & 3 & 2 & 1 \\
\hline $\begin{array}{l}\text { Salutation \& } \\
\text { Closing }\end{array}$ & $\begin{array}{l}\text { Salutation and closing } \\
\text { have no errors in } \\
\text { capitalization and } \\
\text { punctuation. }\end{array}$ & $\begin{array}{l}\text { Salutation and closing } \\
\text { have } 1-2 \text { errors in } \\
\text { capitalization and } \\
\text { punctuation. }\end{array}$ & $\begin{array}{l}\text { Salutation and closing } \\
\text { have } 3 \text { or more errors } \\
\text { in capitalization and } \\
\text { punctuation. }\end{array}$ & $\begin{array}{l}\text { Salutation and/or } \\
\text { closing are missing. }\end{array}$ \\
\hline Length & $\begin{array}{l}\text { The letter is } 10 \text { or } \\
\text { more sentences. }\end{array}$ & $\begin{array}{l}\text { The letter is 8-9 } \\
\text { sentences. }\end{array}$ & $\begin{array}{l}\text { The letter is 5-7 } \\
\text { sentences. }\end{array}$ & $\begin{array}{l}\text { The letter is less than } \\
5 \text { sentences. }\end{array}$ \\
\hline $\begin{array}{l}\text { Grammar \& } \\
\text { Spelling } \\
\text { (conventions) }\end{array}$ & $\begin{array}{l}\text { Writer makes no } \\
\text { errors in grammar or } \\
\text { spelling. }\end{array}$ & $\begin{array}{l}\text { Writer makes 1-2 } \\
\text { errors in grammar } \\
\text { and/or spelling. }\end{array}$ & $\begin{array}{l}\text { Writer makes 3-4 } \\
\text { errors in grammar } \\
\text { and/or spelling }\end{array}$ & $\begin{array}{l}\text { Writer makes more } \\
\text { than } 4 \text { errors in } \\
\text { grammar and/or } \\
\text { spelling. }\end{array}$ \\
\hline $\begin{array}{l}\text { Capitalization } \\
\text { \& Punctuation }\end{array}$ & $\begin{array}{l}\text { Writer makes no } \\
\text { errors in capitalization } \\
\text { and punctuation. }\end{array}$ & $\begin{array}{l}\text { Writer makes } 2-4 \\
\text { errors in capitalization } \\
\text { and punctuation. }\end{array}$ & $\begin{array}{l}\text { Writer makes 4-6 } \\
\text { errors in capitalization } \\
\text { and punctuation. }\end{array}$ & $\begin{array}{l}\text { Writer makes more } \\
\text { than } 6 \text { errors in } \\
\text { capitalization and } \\
\text { punctuation. }\end{array}$ \\
\hline Neatness & $\begin{array}{l}\text { Letter is typed, clean, } \\
\text { not wrinkled, and is } \\
\text { easy to read with no } \\
\text { distracting error } \\
\text { corrections. It was } \\
\text { done with pride. }\end{array}$ & $\begin{array}{l}\text { Letter is neatly hand- } \\
\text { written, clean, not } \\
\text { wrinkled, and is easy } \\
\text { to read with no } \\
\text { distracting error } \\
\text { corrections. It was } \\
\text { done with care. }\end{array}$ & $\begin{array}{l}\text { Letter is typed and is } \\
\text { crumpled or slightly } \\
\text { stained. It may have } 1- \\
2 \text { distracting error } \\
\text { corrections. It was } \\
\text { done with some care. }\end{array}$ & $\begin{array}{l}\text { Letter is typed and } \\
\text { looks like it had been } \\
\text { shoved in a pocket or } \\
\text { locker. It may have } \\
\text { several distracting } \\
\text { error corrections. It } \\
\text { looks like it was done } \\
\text { in a hurry or stored } \\
\text { improperly. }\end{array}$ \\
\hline
\end{tabular}

WAR

\begin{tabular}{|ll|c|r|c|c|c|}
\hline № & & $\begin{array}{l}\text { Salutation\& } \\
\text { closing }\end{array}$ & Length & $\begin{array}{l}\text { Grammar\& } \\
\text { Spelling }\end{array}$ & $\begin{array}{l}\text { Capitalization } \\
\text { \& punctuation }\end{array}$ & Neatness \\
\hline A & P & 4 & 4 & 4 & 3 & 4 \\
\hline B & P & 4 & 3 & 3 & 4 & 3 \\
\hline
\end{tabular}

Having been aware of the results of assignments, in figure 2, I categorized participants as advanced and intermediate learners. The following pie charts describe the percentage of types of motivation in two students. 


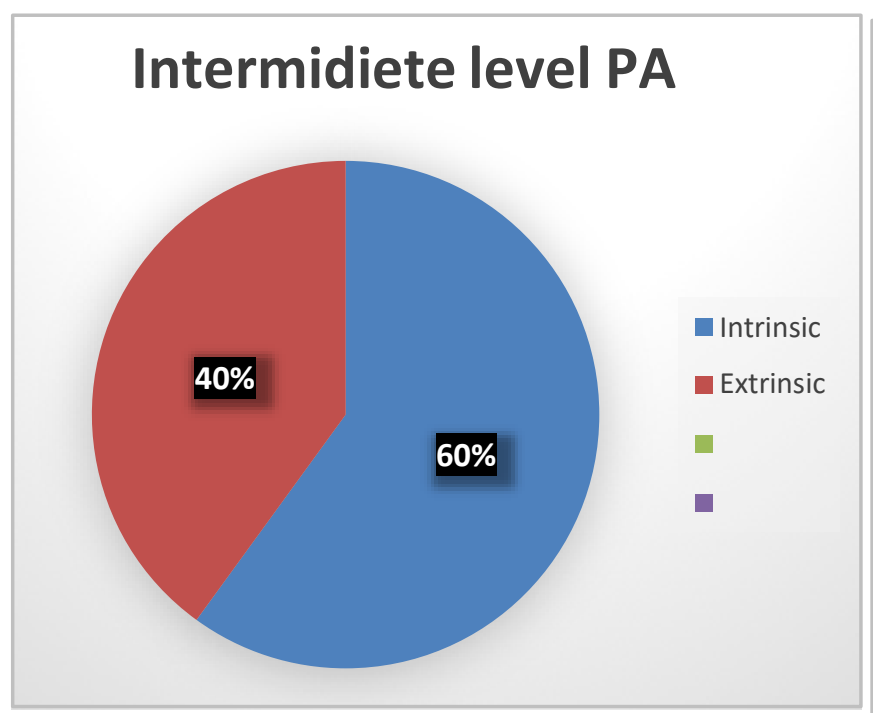

As you see, the answers of Participant A showed that she was more intrinsically motivated while Participant A approached questions intrinsically and extrinsically almost in a similar way.

\section{Conclusion}

In conclusion, both types of motivation play an important role in language learning. However, according to research, intrinsic motivation was more dominant in the learning process. Intrinsically motivated students can get to higher levels than extrinsically motivated students can. My findings demonstrated that starting learning a language before puberty is also vital to accomplish good results in the target language based on learners' results.

The research showed that extrinsically motivated students tend to get a break while studying, leading to some shortcomings in language achievement, while intrinsically motivated students are liable to procrastinate breaks and strive to open new horizons in the target language. Moreover, an intrinsically motivated student is highly under their teachers' influence. The only definition here could be that

\section{Advanced level PB}

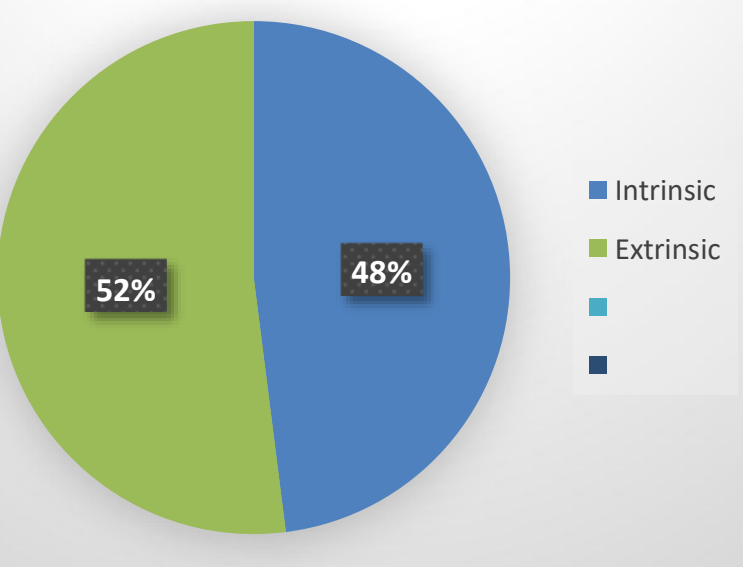

intrinsic motivation may urge them to be more like teachers and follow their instructions. Besides, she spends more hours studying than an extrinsically motivated student. As a result, she reached the advanced level, while participant $B$ stayed at the intermediate level.

\section{REFERENCES}

1. Brown H. D. (2014) Principles of Language Learning and Teaching. 6th ed. Pearson Education, Inc.

2. Clark E. V. (2003). First Language Acquisition. Cambridge University Press2.

3. Gardner, R. (2006). The socio-educational model of second language acquisition: A research paradigm. EUROSLA Yearbook, 6, 237-260.

4. Gardner, R.C., \& Lambert, W.E. (1959). Motivational variables in second language acquisition. Canadian Journal of Psychology: 13, 26 - 72. D,

5. Singleton., L, Ryan. (2004). Language Acquisition: The Age Factor. 2nd ed. Great Britain: Cromwell Press Ltd. 
CURRENT RESEARCH JOURNAL OF PEDAGOGICS 2(10): 30-37,

October 2021 DOI: https://doi.org/10.37547/pedagogics-crjp-02-10-07

ISSN 2767-3278

(C)2021 Master Journals

Crossref do) 81 Google

Accepted 22 $2^{\text {th }}$ October, 2021 \& Published 27th October, 2021

6. Edward, L. Deci. (1973). Intrinsic

Motivation. Rochester University NY

Management

7. Tangriyev, V. A. ., \& Alisherovich Soatov, . I.

. (2021). Language planning and policy proposal for ESL or EFL students and teachers. Current research journal of pedagogics (2767-3278), 2(06), 21-26. https://doi.org/10.37547/pedagogics-

crjp-02-06-06

8. Vallerand., R. J, Pelletier. G, Blais. R, Bierre $\mathrm{N}$, Caroline. (1992). The Academic Motivation Scale: A measure of intrinsic, extrinsic, and motivation in education. Educational and psychological measurement. 52 (4). 1003-1017. 